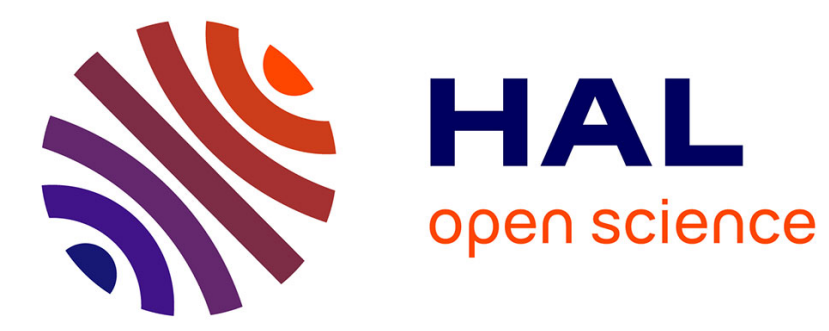

\title{
Fluoroacidity evaluation in molten salts
}

Anne-Laure Bieber, Laurent Massot, Mathieu Gibilaro, Laurent Cassayre, Pierre Chamelot, Pierre Taxil

\section{To cite this version:}

Anne-Laure Bieber, Laurent Massot, Mathieu Gibilaro, Laurent Cassayre, Pierre Chamelot, et al.. Fluoroacidity evaluation in molten salts. Electrochimica Acta, 2011, vol. 56, pp. 5022-5027. 10.1016/j.electacta.2011.03.099 . hal-00813237

\section{HAL Id: hal-00813237 https://hal.science/hal-00813237}

Submitted on 15 Apr 2013

HAL is a multi-disciplinary open access archive for the deposit and dissemination of scientific research documents, whether they are published or not. The documents may come from teaching and research institutions in France or abroad, or from public or private research centers.
L'archive ouverte pluridisciplinaire HAL, est destinée au dépôt et à la diffusion de documents scientifiques de niveau recherche, publiés ou non, émanant des établissements d'enseignement et de recherche français ou étrangers, des laboratoires publics ou privés. 


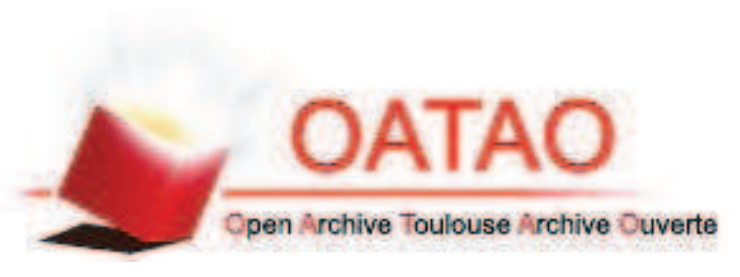

\section{Open Archive Toulouse Archive Ouverte (OATAO)}

OATAO is an open access repository that collects the work of Toulouse researchers and makes it freely available over the web where possible.

This is an author-deposited version published in: http://oatao.univ-toulouse.fr/ Eprints ID: 8614

To link to this article: DOI: $10.1016 /$ j.electacta.2011.03.099

URL : http://dx.doi.org/10.1016/j.electacta.2011.03.099

\section{To cite this version:}

Bieber, Anne-Laure and Massot, Laurent and Gibilaro, Mathieu and Cassayre, Laurent and Chamelot, Pierre and Taxil, Pierre Fluoroacidity evaluation in molten salts. (2011) Electrochimica Acta, vol. 56 ( $\mathrm{n}^{\circ}$ 14). pp. 5022-5027. ISSN 0013-4686 


\title{
Fluoroacidity evaluation in molten salts
}

\author{
A.L. Bieber, L. Massot*, M. Gibilaro, L. Cassayre, P. Chamelot, P. Taxil \\ Laboratoire de Génie Chimique UMR 5503, Département Procédés Electrochimiques, Université de Toulouse, 31062 Toulouse Cedex, France
}

\begin{abstract}
A B S T R A C T
The fluoroacidity of several alkaline fluoride media was studied by monitoring the concentration of electroactive species which is decreasing vs. time due to a gas species release, such as silicon fluorides, as indicated by the reaction: $\mathrm{SiF}_{4+x}{ }^{x-}=\mathrm{SiF}_{4(\mathrm{~g})}+x \mathrm{~F}^{-}$. This article relates the $\mathrm{Si}(\mathrm{IV})$ reaction study to define a relative fluoroacidity scale by studying the silicon ions stability in different melts. Electrochemical techniques allow the measurement of $\mathrm{SiF}_{4+x}{ }^{x-}$ concentration evolution and thus the reaction rate constant to be calculated at different temperatures and for several fluoride media. The article shows that the free $\mathrm{F}^{-}$content depends on the fluoride mixture and that the rate values are correlated with the fluoroacidity allowing a qualitative estimation. Then a fluoride solvents fluoroacidity scale was proposed, scaling the different eutectic melts from basic melt to acidic one: $\mathrm{NaF}-\mathrm{KF}<\mathrm{LiF}-\mathrm{KF}<\mathrm{NaF}-\mathrm{MgF}_{2}<\mathrm{NaF}-\mathrm{CaF}_{2}<\mathrm{LiF}-\mathrm{NaF}<\mathrm{LiF}<\mathrm{LiF}-\mathrm{CaF}_{2}$.
\end{abstract}

\section{Introduction}

The fluoroacidity of a molten salt containing fluoride ions is defined by the free $\mathrm{F}^{-}$content in a bath defined by:

$\mathrm{pF}^{-}=-\log a_{\mathrm{F}^{-}}$

where $a_{\mathrm{F}^{-}}$is the activity of free $\mathrm{F}^{-}$ions in the mixture.

The $\mathrm{pF}^{-}$role is similar to the $\mathrm{pH}$ for protic solvent, hence it is a key parameter in molten fluorides for applications such as electrodeposition. The fluoroacidity influences the solute ions coordinancy in the medium and thus the physico-chemical properties of the molten solutions. For the expression of the acid-base equilibrium of the fluoride solution, a similar concept early developed in chloride medium was used and reported in [1] and assessing the following equilibrium:

chlorobase $=$ chloroacid $+n \mathrm{Cl}^{-}$

This equation expresses the chloroacidity notion, where the solvent species dissociation releases chloride anions $\mathrm{Cl}^{-}$, used for acids and bases definition. Following a similar approach in fluoride media, the fluoroacidity is based on an $\mathrm{F}^{-}$exchange in the mixture, the basic form being $\mathrm{F}^{-}$givers and acidic form being $\mathrm{F}^{-}$acceptors, as expressed in Eq. (3):

fluorobase $=$ fluoroacid $+n \mathrm{~F}^{-}$

The main difficulty for constructing thermodynamic diagrams (e.g. Pourbaix diagram for aqueous solution) in fluoride media is

\footnotetext{
* Corresponding author. Tel.: +33 561558194; fax: +33 561556139

E-mail address: massot@chimie.ups-tlse.fr (L. Massot).
}

the lack of thermodynamic data, due to the unavailability of a stable reference electrode [2], explaining why only very few fluoroacidity studies in molten fluorides have been dedicated to this concept, except those performed in cryolithe media $\left(\mathrm{Na}_{3} \mathrm{AlF}_{6}\right)$, used as electrolyte for aluminium production [3]. A key parameter is the acidity of the bath, which refers to the $\mathrm{AlF}_{3}$ concentration. Dewing [4] defined a coefficient describing the acid/base character of a given component in the cryolite mixture. Many additives were sorted from weak base to strong acid: $\mathrm{BaF}_{2}<\mathrm{SrF}_{2}<\mathrm{LiF}<\mathrm{CaF}_{2}<\mathrm{BeF}_{2}<\mathrm{MgF}_{2}$ [4-6].

Fluoroacidity has to be studied for a better knowledge of the melt acidic properties modifying the physico-chemical properties of a solute. In the case of silicon ions in molten fluorides, Elwell[7] studied the $\mathrm{Si}(\mathrm{IV})$ volatility difference in $\mathrm{BaF}_{2}, \mathrm{CaF}_{2}, \mathrm{MgF}_{2}$ and $\mathrm{NaF}$ or KF mixtures concluding that $\mathrm{Si}(\mathrm{IV})$ is better stabilized in $\mathrm{NaF}-\mathrm{BaF}_{2}$. Nohira [8] demonstrated that LiCl-KCl-LiF silicon oxidation produced two compounds which are in equilibrium: $\mathrm{SiF}_{4(\mathrm{~g})}$ and $\mathrm{SiF}_{6}{ }^{2-}$ as proposed in Eq. (4):

$\mathrm{SiF}_{6(\sin )}^{2-}=\mathrm{SiF}_{4(g)}+2 \mathrm{~F}^{-}$

As it is stated that fluoroacidity influences the cations coordinancy in the bath, $\mathrm{Si}(\mathrm{IV})$ ions have to be expressed as: $\mathrm{SiF}_{4+x}{ }^{x-}$. So Eq. (4) has to be amended, as written in Eq. (5):

$\mathrm{SiF}_{4+x}^{x-}=\mathrm{SiF}_{4(g)}+x \mathrm{~F}^{-}$

According to the definition of fluoroacidity, the higher the $\mathrm{F}^{-}$ concentration, the more basic the molten solution. So, the Si(IV) equilibrium study allows evaluating the fluoroacidity since a basic bath contributes to the silicon ions stabilization. Electrochemical techniques (cyclic and square wave voltammetries) were used in order to measure $\mathrm{SiF}_{4+x}{ }^{x-}$ concentration vs. time. To correlate the 


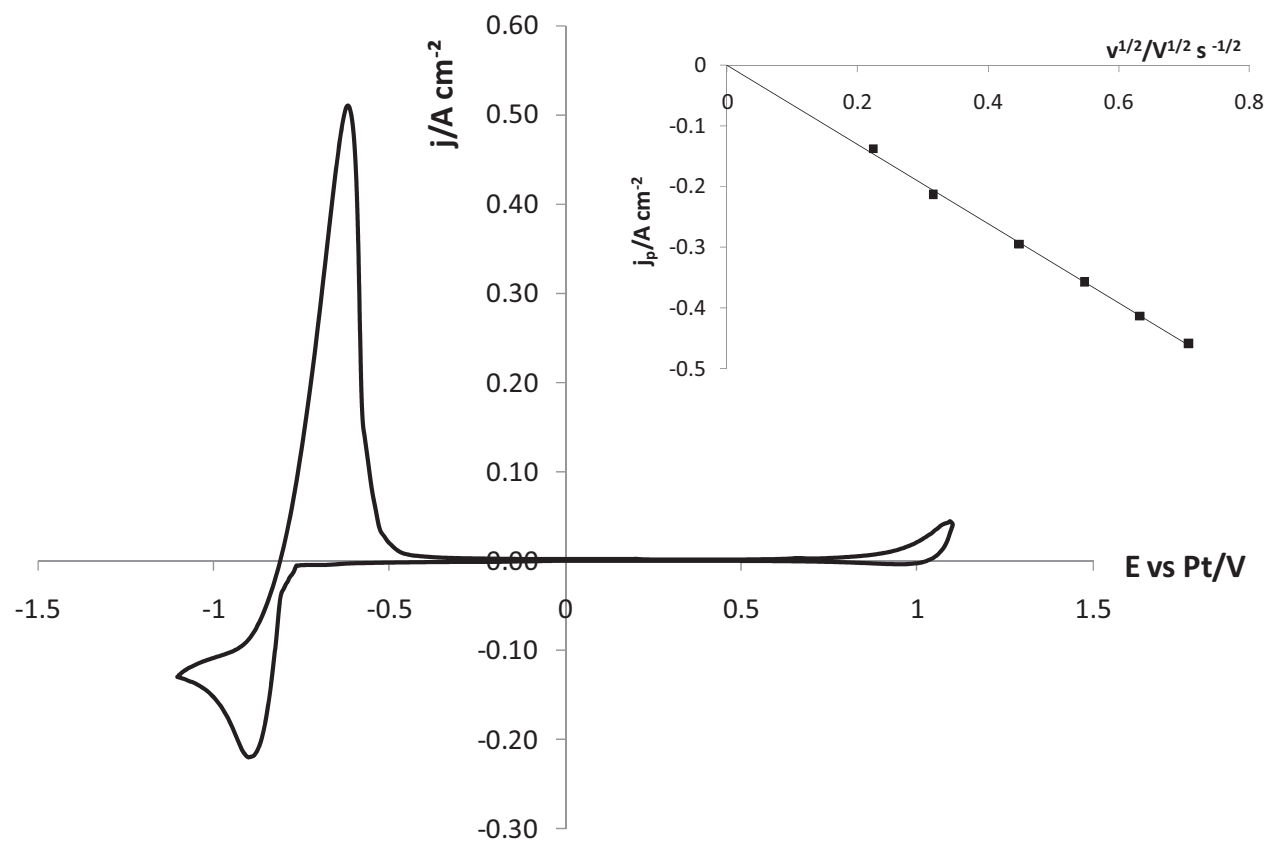

Fig. 1. Cyclic voltammogram of LiF-KF-K $\mathrm{K}_{2} \mathrm{SiF}_{6}\left(9.9 \times 10^{-2} \mathrm{~mol} \mathrm{~kg}^{-1}\right)$; Working electrode: Ag; Auxiliary el.: vitreous carbon; Reference el.: Pt; $\mathrm{Scan}$ rate $=100 \mathrm{mV}{ }^{-1} ; t=800{ }^{\circ} \mathrm{C}$ / Inset: Linear relationship of $\mathrm{Si}(\mathrm{IV})$ reduction peak current density vs. the square root of the scanning potential rate.

peak current density of the Si ions reduction with their concentration, the Si(IV) electroreduction mechanism has to be known.

Studies on $\mathrm{Si}$ (IV) electroreduction have been reported by several authors [9-13]. The deposition mechanism of silicon from $\mathrm{NaCl}-\mathrm{KCl}-\mathrm{K}_{2} \mathrm{SiF}_{6}$, proposed by Delimarskii [9], involves a single reduction wave on a molybdenum electrode. Rao and Elwell [10] agreed that in $\mathrm{LiF}-\mathrm{NaF}-\mathrm{KF}$, the $\mathrm{K}_{2} \mathrm{SiF}_{6}$ reduction in $\mathrm{Si}$ is a one step process with a charge transfer limitation. According to references $[9,10], \mathrm{Si}(\mathrm{IV})$ is reduced in a single step:

$\mathrm{Si}(\mathrm{IV})+4 e^{-}=\mathrm{Si}$

However, Chernov et al. [11] proposed that the silicon reduction proceeds in two stages on a platinum cathode in $\mathrm{NaCl}-\mathrm{KCl}$ at $685^{\circ} \mathrm{C}$, which was confirmed by De Lepinay et al. [12] in LiF-KF and $\mathrm{LiF}-\mathrm{NaF}-\mathrm{KF}$ between 550 and $850^{\circ} \mathrm{C}$ as:

$\mathrm{Si}(\mathrm{IV})+2 e^{-}=\mathrm{Si}(\mathrm{II})$

$\mathrm{Si}(\mathrm{II})+2 e^{-}=\mathrm{Si}$

Kuznetsova et al. [13] showed that a possible silicides formation before Si deposition, coming from a reaction between the electrode and the silicon, could explain the presence of a second wave found in the study of Chernov [11]. To avoid this phenomenon, a silver working electrode was preferred in our work since there is no $\mathrm{Ag}-\mathrm{Si}$ intermetallic compounds [14]. The LiF-KF mixture was chosen to begin this study since many silicon electrodeposition studies in molten fluorides were carried out in this medium $[12,15,16]$.

This paper is divided into two parts:

- The electroreduction process in order to conclude on the reduction pathway of the Si(IV) into Si.

- The kinetics of $\mathrm{SiF}_{4(\mathrm{~g})}$ release in relation with the fluoroacidity of the melts.

The $\mathrm{SiF}_{4(\mathrm{~g})}$ release rate was thus measured in several media (NaF-KF, LiF-KF, NaF-MgF $, \mathrm{NaF}_{2}-\mathrm{CaF}_{2}, \mathrm{LiF}-\mathrm{NaF}, \mathrm{LiF}, \mathrm{LiF}-\mathrm{CaF}_{2}$ ) and a fluoroacidity scale is proposed.

\section{Experimental}

The cell was a vitreous carbon crucible placed in a cylindrical vessel made of refractory steel and closed by a stainless steel lid cooled by circulating water. This cell has been described in previous work [17]. The experiments were performed under an inert argon atmosphere (Linde). The cell was heated using a programmable furnace and the temperatures were measured using a chromel-alumel thermocouple.

\subsection{Electrolyte}

Several molten salts (Carlo Erba 99.995\%) were used as electrolyte solvent: LiF-KF (51-49 mol\%), LiF-NaF (60-40 mol\%), $\mathrm{NaF}-\mathrm{KF} \quad(40-60 \mathrm{~mol} \%), \quad \mathrm{NaF}-\mathrm{MgF}_{2} \quad(78-22 \mathrm{~mol} \%), \quad \mathrm{NaF}-\mathrm{CaF}_{2}$ (69-31 mol\%), $\mathrm{LiF}-\mathrm{CaF}_{2}(80-20 \mathrm{~mol} \%)$. All the solvent were initially dehydrated by heating under vacuum $\left(7 \times 10^{-2} \mathrm{~atm}\right)$ from ambient temperature up to their melting point during one week. Silicon ions were introduced into the bath in the form of potassium or sodium hexafluorosilicate $\mathrm{K}_{2} \mathrm{SiF}_{6}$ or $\mathrm{Na}_{2} \mathrm{SiF}_{6}$ (Alfa Aesar 99.99\%) powder.

\subsection{Electrodes}

Silver wires ( $1 \mathrm{~mm}$ diameter) were used as working electrode. The electrode surface area was determined after each experiment by measuring the wire immersion depth in the bath. The auxiliary electrode was a vitreous carbon (V25) rod (3 mm diameter) with a large surface area $\left(2 \mathrm{~cm}^{2}\right)$. The potentials were measured with reference to a platinum wire $(0.5 \mathrm{~mm}$ diameter $)$ immersed in the molten electrolyte [18,19].

\subsection{Electrochemical techniques}

Cyclic voltammetry and square wave voltammetry were used for the investigation of the mechanism of $\mathrm{Si}(\mathrm{IV})$ ions reduction. All the electrochemical studies were performed with an AutolabPGStat 30 potentiostat/galvanostat controlled by a computer using the research software GPES. 


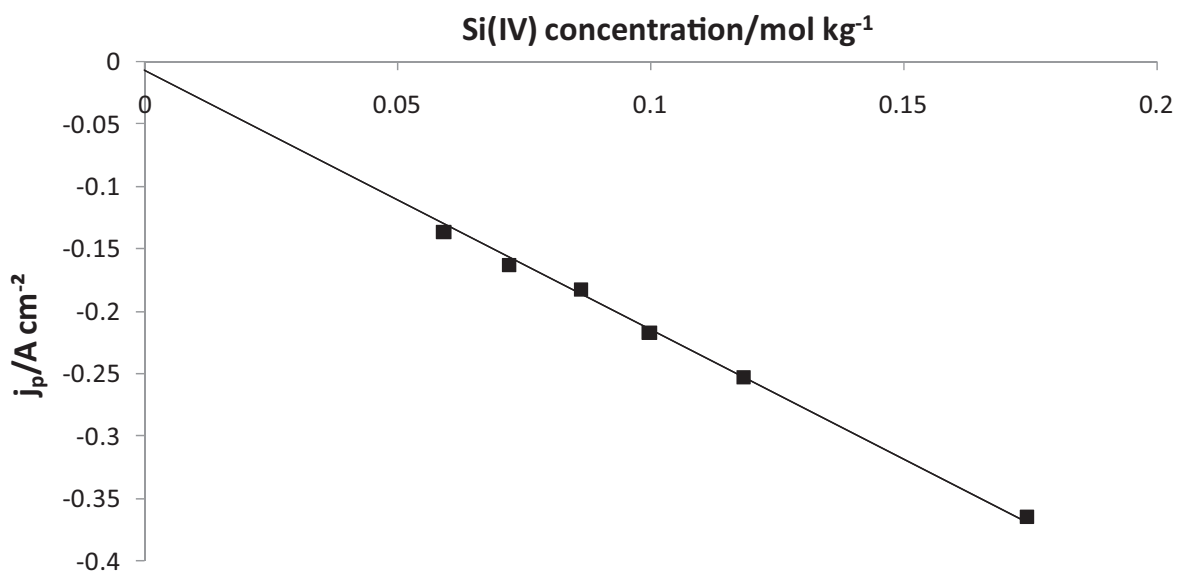

Fig. 2. Linear relationship between reduction peak current density and Si(IV) concentration in the bath measured by ICP; Working electrode: Ag; Auxiliary el.: vitreous carbon; Reference el.: Pt; Scan rate $=100 \mathrm{mV} \mathrm{s}^{-1} ; t=800^{\circ} \mathrm{C}$.

\section{Results and discussion}

\section{1. $\mathrm{Si}(\mathrm{IV})$ reduction mechanism}

\subsubsection{Cyclic voltammetry}

Cyclic voltammetry was carried out on a silver electrode in LiF-KF- $\mathrm{K}_{2} \mathrm{SiF}_{6}$ system in the $700-900{ }^{\circ} \mathrm{C}$ temperature range. Fig. 1 presents a typical cyclic voltammogramm of the $\mathrm{LiF}-\mathrm{KF}-\mathrm{K}_{2} \mathrm{SiF}_{6}$ $\left(0.35 \mathrm{~mol} \mathrm{~kg}^{-1}\right)$ system at $800^{\circ} \mathrm{C}$ on silver electrode. This cyclic voltammogramm exhibits only one reduction peak at $-0.9 \mathrm{~V} v \mathrm{vs}$. Pt and its associated reoxidation peak at $-0.65 \mathrm{~V}$ vs. Pt. The asymmetrical shape of the reoxidation peak is typical of the redissolution of a solid phase deposited during the cathodic run (stripping peak). The linear relationship between $\mathrm{Si}(\mathrm{IV}$ ) reduction peak intensity and the square root of the scan rate has been verified in the inset of Fig. 1, proving that the electrochemical reduction process is controlled by the $\mathrm{Si}(\mathrm{IV})$ ions diffusion in the bath (Berzins Delahay [20] valid for a reversible soluble/insoluble system):

$I_{p}=-0.61 n \mathrm{FSc}^{0}\left(\frac{n \mathrm{FD}}{\mathrm{RT}}\right)^{1 / 2} V^{1 / 2}$

where $n$ is the number of exchanged electrons, $\mathrm{F}$ is the Faraday's constant $\left(\mathrm{C} \mathrm{mol}^{-1}\right), S$ is the electrode surface area $\left(\mathrm{cm}^{2}\right), c^{0}$ is the solute concentration $\left(\mathrm{mol} \mathrm{cm}^{-3}\right), D$ is the diffusion coefficient $\left(\mathrm{cm}^{2} \mathrm{~s}^{-1}\right), T$ is the temperature $(\mathrm{K})$ and $V$ is the potential scan rate $\left(V \mathrm{~s}^{-1}\right)$.

The Si(IV) concentration in the bath was measured by sampling the bath after each $\mathrm{Si}(\mathrm{IV})$ additions and dissolution in acidic media, using Inductively Coupled Plasma-Atomic Emission Spectrocopy (ICP-AES). A linear relationship between the cathodic peak intensity and the silicon ions concentration has been plotted in Fig. 2, confirming that the cathodic peak can be attributed to the Si(IV) ions reduction into Si. The relation between peak intensity and silicon concentration gives at $800^{\circ} \mathrm{C}$ :

$j_{p}=-2.14[\mathrm{Si}(\mathrm{IV})]$

Using Eq. (10) and the slope of Fig. 1 inset, the diffusion coefficient value is $(4.7 \pm 0.2) \times 10^{-6} \mathrm{~cm}^{2} \mathrm{~s}^{-1}$ in $\mathrm{LiF}-\mathrm{KF}-\mathrm{K}_{2} \mathrm{SiF}_{6}$ at $800^{\circ} \mathrm{C}$. Kuznetsova found a $\mathrm{Si}(\mathrm{IV})$ ions diffusion coefficient equal to $(1.64 \pm 0.25) \times 10^{-5} \mathrm{~cm}^{2} \mathrm{~s}^{-1}$ at $750{ }^{\circ} \mathrm{C}$ in a $\mathrm{NaCl}(43.25 \mathrm{~mol} \%)-\mathrm{KCl}$ (43.25 mol\%)-NaF (13.50 mol\%)- $\mathrm{K}_{2} \mathrm{SiF}_{6}$ mixture [13]. The difference between the values can be explained by the temperature and medium effects, which imply a fluoroacidity difference.

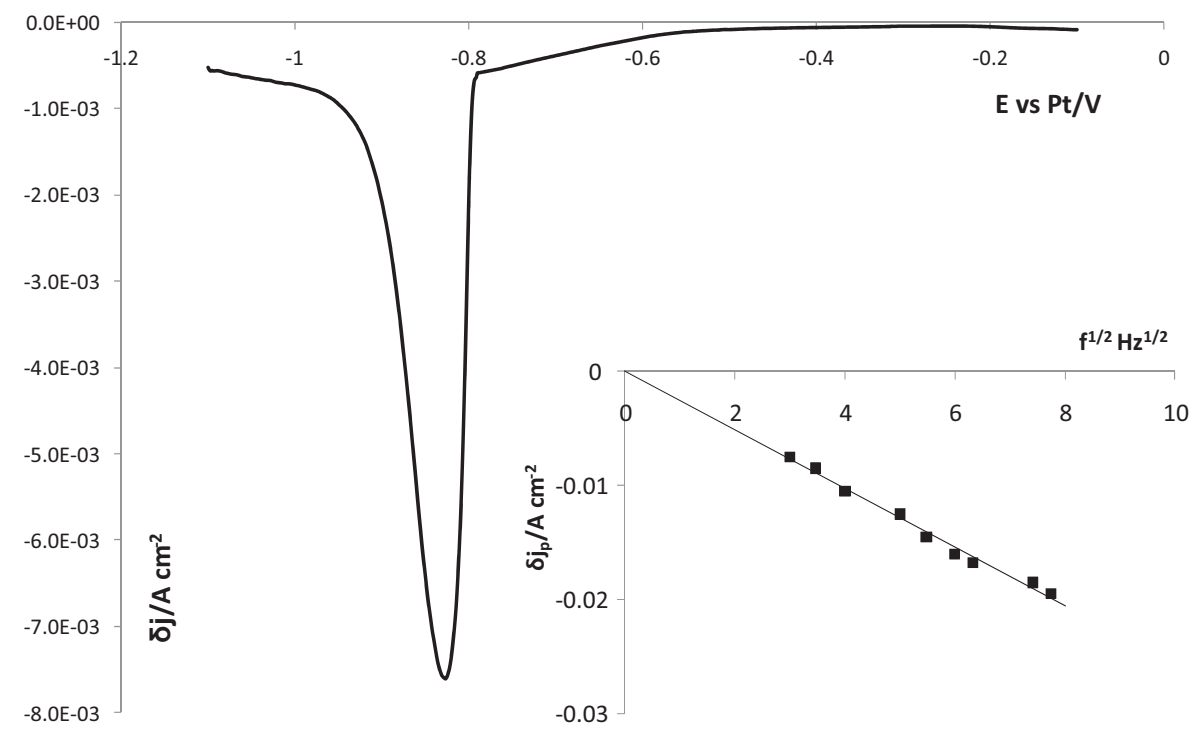

Fig. 3. Square wave voltammogram of the LiF-KF- $\mathrm{K}_{2} \mathrm{SiF}_{6}\left(14.2 \times 10^{-2} \mathrm{~mol} \mathrm{~kg}^{-1}\right)$; Working electrode: $\mathrm{Ag}\left(\right.$ surface area $\left.=0.31 \mathrm{~cm}^{2}\right)$; Auxiliary el.: vitreous carbon; Reference el.: Pt; Frequency $=9 \mathrm{~Hz} ; t=800{ }^{\circ} \mathrm{C} /$ Inset: Linear relationship of $\mathrm{Si}(\mathrm{IV})$ reduction peak current density vs. the square root of the scanning potential rate. 


\subsubsection{Square wave voltammetry}

The square wave voltammetry was used to confirm the number of exchanged electrons of $\mathrm{Si}$ (IV) reduction, as the half-width of a peak is linked to the number of exchanged electrons [21]:

$W_{1 / 2}=3.52 \frac{\mathrm{RT}}{\mathrm{nF}}$

where $W_{1 / 2}$ represents the half-width of a peak (V).

Fig. 3 shows a square wave voltammogramm of the $\mathrm{LiF}-\mathrm{KF}-\mathrm{K}_{2} \mathrm{SiF}_{6}\left(0.57 \mathrm{~mol} \mathrm{~kg}{ }^{-1}\right)$ system on a silver electrode at $800^{\circ} \mathrm{C}$ at $9 \mathrm{~Hz}$. The shape is an asymmetrical Gaussian curve, characteristic of a soluble/insoluble system [22,23]. The Eq. (11) is valid if the peak current density is linear with the square root of the frequency [24], which is verified in the inset of Fig. 3. The peak dissymmetry is due to the currentless nucleation overvoltage, associated with formation of the solid phase on the electrode, which delays the current growth $[25,26]$. The deconvolution of the experimental signal allows finding the number of electrons using the semi half-width in the part of the voltammogram unaffected by the nucleation phenomenon [22]. The calculation of the number of electrons exchanged for silicon electrodeposition gives $n=3.9 \pm 0.1$. These results allow concluding that the silicon reduction in molten salts is a one-step process exchanging four electrons as mentioned in Eq. (6).

\subsection{Kinetics of $\mathrm{SiF}_{4(\mathrm{~g})}$ release}

According to the Eq. (5), the $\mathrm{SiF}_{4(\mathrm{~g})}$ release leads to a $\mathrm{Si}(\mathrm{IV})$ peak intensity decrease. Consequently, this reaction was used to compare the fluoroacidity of the molten fluorides, as the free $\mathrm{F}^{-}$content in the bath acts on the equilibrium constant and thus on the kinetic rate of $\mathrm{SiF}_{4(\mathrm{~g})}$ release. To study the kinetics of $\mathrm{SiF}_{4(\mathrm{~g})}$ release in the mixture, the variation of the Si(IV) ions concentration was plotted vs. time after an addition of $\mathrm{K}_{2} \mathrm{SiF}_{6}\left(0.57 \mathrm{~mol} \mathrm{~kg}^{-1}\right)$ in $\mathrm{LiF}-\mathrm{KF}$ at $800^{\circ} \mathrm{C}$. In Fig. 4, the plot is divided into two parts.

The first part of the curve where the peak current density increases corresponds to the $\mathrm{K}_{2} \mathrm{SiF}_{6}$ dissolution in the bath, up to a maximum value depending on the nature of the bath and the temperature. The $\mathrm{K}_{2} \mathrm{SiF}_{6}$ dissolution time was shorter than the evaporation rate of silicon species. Then, the silicon current density decreases due to the reaction described in Eq. (5). The second part has a logarithm shape likely corresponding to a first order kinetic. By plotting the logarithm of the Si(IV) concentration vs. time as expected is a straight line, according to the Eq. (12), shown in Fig. 5, demonstrating that the equilibrium reaction kinetics is a first order one.

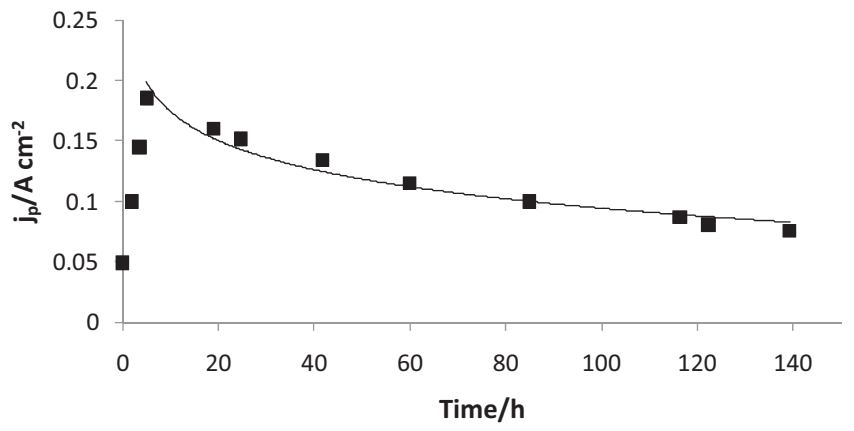

Fig. 4. Evolution of the silicon reduction peak current density vs. time after an addition of $\mathrm{K}_{2} \mathrm{SiF}_{6}$ at $t=0$; Working electrode: Ag; Auxiliary el.: vitreous carbon; Reference el.: Pt; $t=800^{\circ} \mathrm{C}$.

The measurement of the Si(IV) concentration allows the kinetic rate of $\mathrm{SiF}_{4(\mathrm{~g})}$ release (first order) to be calculated:

$\mathrm{v}=-\frac{\mathrm{d}[\mathrm{Si}(\mathrm{IV})]}{\mathrm{dt}}=k[\mathrm{Si}(\mathrm{IV})]$

where $k$ is the kinetic constant $\left(\mathrm{s}^{-1}\right),[\mathrm{Si}(\mathrm{IV})]$ is the dissolved silicon concentration $\left(\mathrm{mol} \mathrm{kg}^{-1}\right)$ and $\mathrm{v}$ is rate reaction $\left(\mathrm{mol} \mathrm{kg}^{-1} \mathrm{~s}^{-1}\right)$.

The determination of $k$ is a classical methodology of first order kinetics:

$\ln [\mathrm{Si}(\mathrm{IV})]=-k \mathrm{t}+\mathrm{constant}$

Plotting $\ln [\mathrm{Si}(\mathrm{IV})]$ vs. time leads to the value of the rate constant $k$ of $\mathrm{SiF}_{4(\mathrm{~g})}$ release. According to the slope of the curve, the rate constant value is $19 \times 10^{-7} \mathrm{~s}^{-1}$ at $800^{\circ} \mathrm{C}$. The plotting of $\ln [\mathrm{Si}(\mathrm{IV})] \mathrm{vs}$. time at other temperatures allows calculating $k$ at these temperatures; the obtained values should obey the Arrhenius' law:

$k=A \exp \left(-\frac{E_{a}}{\mathrm{RT}}\right)$

where $E_{\mathrm{a}}$ is the activation energy $\left(\mathrm{J} \mathrm{mol}^{-1}\right)$ and $A$ the preexponential factor $\left(\mathrm{s}^{-1}\right)$.

This assumption has been verified in Fig. 6 where the plot of the rate constant logarithm vs. the inverse of temperature is linear with a slope correlated to the activation energy. For LiF-KF eutectic, the activation energy is found to be around $213 \mathrm{~kJ} \mathrm{~mol}^{-1}$ and the pre-exponential factor $47 \times 10^{3} \mathrm{~s}^{-1}$.

This rate constant is correlated to the fluoroacidity of each bath and allows sorting different mixtures fluoroacidity. A low rate constant means that the silicon ions remain in the bath. Consequently, the apparent stability of these ions is favored and, according to Eq. (5), the salt mixture is assumed to be basic. In the next paragraph,

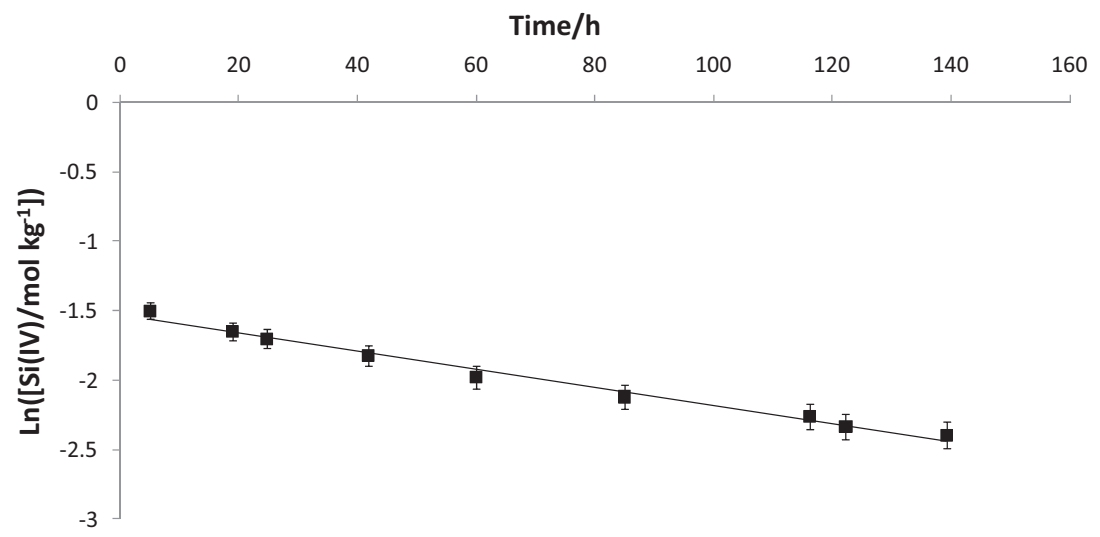

Fig. 5. Linear relationship of the logarithm of the Si(IV) concentration in the bath vs. time; $t=800^{\circ} \mathrm{C}$. 


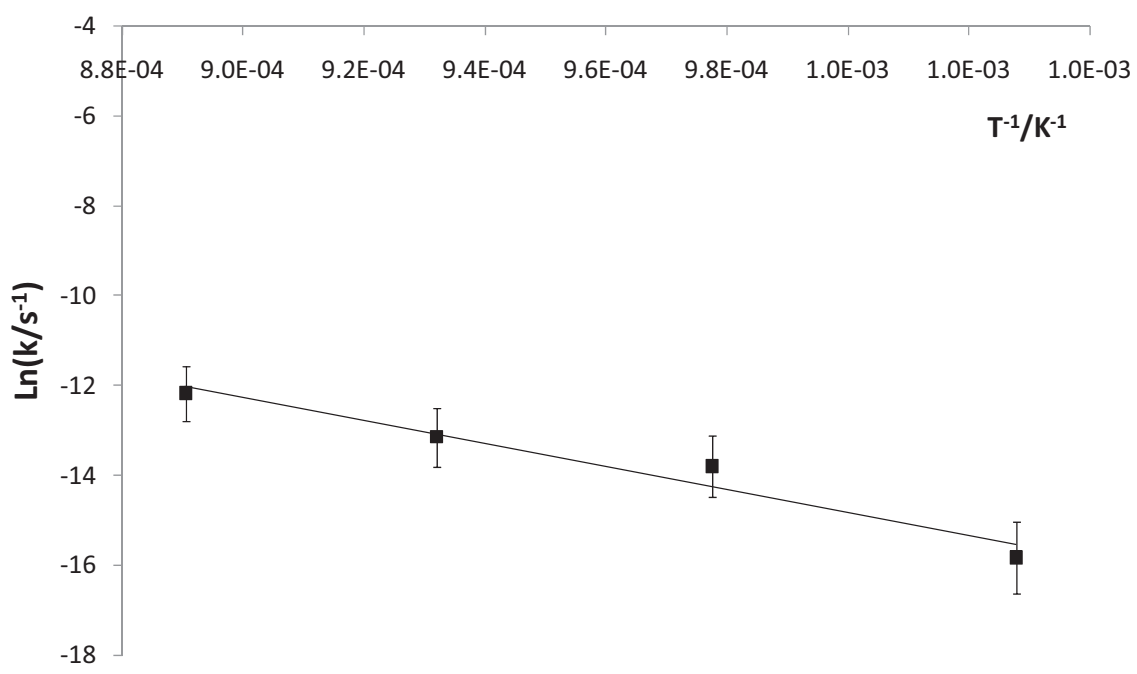

Fig. 6. Linear relationship of the logarithm of the rate constant of the $\mathrm{Si}(\mathrm{IV})$ ions release $(k)$ vs. the inverse of temperature; $t=800{ }^{\circ} \mathrm{C}$.

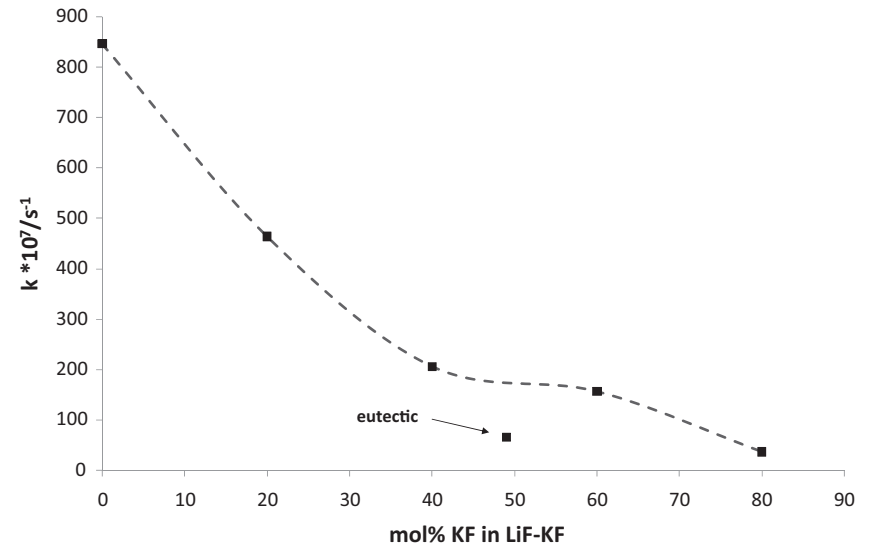

Fig. 7. Rate constant of $\mathrm{Si}(\mathrm{IV})$ ions release $(k)$ in LiF-KF mixtures at $t=900^{\circ} \mathrm{C}$.

the operating conditions comparison is presented, concerning the salt composition and the mixture choice.

\subsection{Comparison of operating conditions}

\subsubsection{Influence of LiF-KF composition}

The values of the kinetic constant of reaction (5) are gathered in Fig. 7 for several compositions of $\operatorname{LiF}-\mathrm{KF}$ (0, 20, 40, 49 (eut.), $60,80 \mathrm{~mol} \%$ ). The medium composition influence was studied for a LiF-KF mixture because it can include the study of pure LiF due to its low vapour pressure, whereas pure $\mathrm{KF}$ and $\mathrm{NaF}$ cannot be experimented due to a too high vapour pressure for KF and a too high melting point for $\mathrm{NaF}\left(996^{\circ} \mathrm{C}\right)$. Fig. 7 presents the $\mathrm{SiF}_{4(\mathrm{~g})}$ release rate constants determined at a temperature of $900^{\circ} \mathrm{C}$ for each studied media. We observe that, when the KF content increases, the rate constant value decreases, meaning that the mixture tends to be more and more basic. It can be concluded that $\mathrm{KF}$ is more basic than LiF. Concerning the $51 \mathrm{~mol} \% \mathrm{LiF}-49 \mathrm{~mol} \% \mathrm{KF}$ composition, the rate constant is lower than expected from the variation of $k$ for other compositions, meaning that the bath is stable. Notice that the lowest value of rate constant was found for the LiF-KF (20-80 mol\%). For this mixture $\left(t_{\mathrm{m}}=759^{\circ} \mathrm{C}\right)$, a high volatility is observed at high temperature. To avoid this phenomenon, the second lowest value of rate constant was chosen, corresponding for a salt mixture, to the eutectic composition. The results concerning the rate constant of eutectic mixture of other binary fluoride systems are presented and discussed in the next paragraph.

\subsubsection{Influence of binary mixtures}

The values of $k$ for other fluoride media are gathered in Table 1. The precision of rate constants is comprised between $2 \%$ for basic baths (high KF content) and 8\% for more acidic ones, due to shorter experiment duration. The results are presented for eutectic compositions salts: the left part is composed of monovalent salts whereas in the right part the mixtures are composed of one monovalent and one divalent ion. The comparison of the fluoroacidity of these mixtures was done at the same temperature of $900^{\circ} \mathrm{C}$. Thanks to Eq. (14), the temperature dependence of $k$ is known, thus allowing different mixtures to be compared. Indeed, a too high difference between the melting point and the experimental temperature is not suitable for avoiding the salt distillation (about $250^{\circ} \mathrm{C}$ ).

Table 1

Rate constant of $\mathrm{Si}(\mathrm{IV})$ ions release ( $k$ ) for different fluoride media at different temperature; italic values calculating with Eq. (14).

\begin{tabular}{|c|c|c|c|c|c|c|c|}
\hline \multicolumn{8}{|l|}{$10^{7} \mathrm{k} / \mathrm{s}^{-1}$} \\
\hline$t\left({ }^{\circ} \mathrm{C}\right)$ & $\mathrm{LiF}$ & $\mathrm{NaF}-\mathrm{KF}$ & LiF-KF & LiF-NaF & $\mathrm{NaF}-\mathrm{MgF}_{2}$ & $\mathrm{NaF}-\mathrm{CaF}_{2}$ & $\mathrm{LiF}-\mathrm{CaF}_{2}$ \\
\hline Melting point & 848 & 718 & 492 & 652 & 835 & 814 & 760 \\
\hline Molar comp. & & $40-60$ & $51-49$ & $60-40$ & $78-22$ & $69-31$ & $80-20$ \\
\hline 700 & & & 1.2 & 36.2 & & & \\
\hline 750 & & 2.8 & 12.3 & 79.0 & & & \\
\hline 800 & & 3.3 & 19.1 & 178 & & & \\
\hline 820 & & 5.5 & 24.5 & 201 & & & 540 \\
\hline 850 & & 8.0 & 57.6 & 268 & & & 2083 \\
\hline 900 & 846 & 12.2 & 65.3 & 523 & 92.1 & 243 & 4876 \\
\hline 950 & & 15.6 & 252 & 984 & 299 & 437 & 18170 \\
\hline
\end{tabular}




\begin{tabular}{|lllllll|}
\multicolumn{1}{c|}{ Basic } \\
\hline NaF-KF & LiF-KF & NaF-MgF & NaF-CaF & LiF-NaF & LiF & LiF-CaF $_{2}$ \\
$40-60$ & $51-49$ & $78-22$ & $69-31$ & $60-40$ & & $80-20$ \\
$718^{\circ} \mathrm{C}$ & $492^{\circ} \mathrm{C}$ & $835^{\circ} \mathrm{C}$ & $814^{\circ} \mathrm{C}$ & $652^{\circ} \mathrm{C}$ & $848^{\circ} \mathrm{C}$ & $760^{\circ} \mathrm{C}$ \\
\hline
\end{tabular}

Fig. 8. Qualitative fluoroacidity scale of the eutectics of different baths; 1st line: fluorides eutectics; 2nd line: mixture composition; 3rd line: liquidus temperature.

The $\mathrm{Si}(\mathrm{IV})$ rate constant is the lowest for NaF-KF meaning that it is the most basic bath. All the results are gathered on Fig. 8 in a qualitative scale representing mixtures from the most basic bath to the most acidic one.

The left side of Table 1 demonstrates the role of KF in the basicity of the melts: for example, $\mathrm{KF}-\mathrm{NaF}(60-40 \mathrm{~mol} \%)$ is more basic than LiF-NaF (60-40 mol\%), while the NaF content is identical in each mixture; thus the difference of fluoroacidity is influenced by the counter-ion: KF is more basic than LiF. Likewise LiF-KF is more basic than LiF-NaF while the composition in LiF is similar, that means that $\mathrm{KF}$ is more basic than NaF. Moreover if we compare NaF-KF and $\mathrm{LiF}-\mathrm{KF}, \mathrm{NaF}$ is more basic than LiF. Hence for monovalent ions, we can assume that the fluoroacidity scale is $\mathrm{KF}<\mathrm{NaF}<\mathrm{LiF}$. The experiments with divalent ions are more difficult to interpret because the compositions of divalent compounds are too different. Nevertheless, the $\mathrm{LiF}$ and $\mathrm{LiF}-\mathrm{CaF}_{2}$ comparison allows concluding that $\mathrm{CaF}_{2}$ is more acidic than LiF.

\section{Conclusion}

The equilibrium between $\mathrm{Si}(\mathrm{IV})$ ions and $\mathrm{SiF}_{4(\mathrm{~g})}$ in molten fluorides is highly influenced by the solvent cations. In cyclic voltammograms, the Si(IV) reduction peak intensity decreases vs. time. So, kinetics of $\mathrm{SiF}_{4(\mathrm{~g})}$ release depends on the bath fluoroacidity, since a bath containing a high free $\mathrm{F}^{-}$ions concentration contributes to stabilizing silicon ions in the medium. Using these reaction kinetics results, the following scale of fluoroacidity was established from most basic to most acidic: $\mathrm{NaF}-\mathrm{KF}<\mathrm{LiF}-\mathrm{KF}<\mathrm{NaF}-\mathrm{MgF}_{2}<\mathrm{NaF}-\mathrm{CaF}_{2}<\mathrm{LiF}-\mathrm{NaF}<\mathrm{LiF}<\mathrm{LiF}-\mathrm{CaF}_{2}$. The comparison of the acidity of these mixtures proved that the most basic compounds are monovalents as $\mathrm{KF}<\mathrm{NaF}<\mathrm{LiF}$. A higher valency of divalent compounds favours an acidic behaviour but the comparison between $\mathrm{CaF}_{2}$ and $\mathrm{MgF}_{2}$ is experimentally difficult to perform. For acidic baths, the $k$ value is hard to determine due to the uncertainty of experimental data. To confirm these results and for a better acid baths fluoroacidity evaluation, a similar system with a species in equilibrium with a gaseous compound should be studied. Finally a perspective of this work will be the achievement of a quantitative fluoroacidity scale.

\section{Acknowledgements}

The authors express their thanks to the Research National Agency ANR-09-BLAN-0188 for their financial support for this research.

\section{References}

[1] B. Tremillon, G. Letisse, J. Electroanal. Chem. 17 (1968) 371.

2] P. Chamelot, J.C. Poignet, in: V. Ghetta, J. Fouletier, P. Taxil (Eds.), Sels Fondus à Haute Température, Presses Polytechniques et Universitaires Romandes, Lausanne, 2009, p. 78.

[3] E.W. Dewing, Can. Metall. Quart. 30 (1991) 153.

[4] E.W. Dewing, Metall. Trans. B 20B (1989) 675.

[5] E. Robert, PhD Thesis Université de Liège (1998).

[6] B. Gilbert, E. Robert, T.E., O.J.E., O.T., Inorg. Chem., 35 (1996) 4198

[7] D. Elwell, Sol. Energ. Mater. 5 (1981) 205.

[8] T. Nohira, D. Miura, Y. Ito, Electrochemistry 73 (2005) 692.

[9] Y.K. Delimarskii, A.G. Golov, A.P. Nizov, R.V. Chernov, Ukr. Khim. Zh. 34 (12) (1968) 1227.

[10] D. Elwell, G.M. Rao, Electrochim. Acta 27 (1982) 673

[11] R.V. Chernov, A.P. Nizov, Y.K. Delimarskii, Ukr. Khim. Zh. 37 (1971) 422.

[12] J. De Lepinay, J. Bouteillon, S. Traore, D. Renaud, M.J. Barbier, J. Appl. Electrochem. 17 (1987) 294.

[13] S.V. Kuznetsova, V.S. Dolmatov, S.A. Kuznetsov, Russ. J. Electrochem. 45 (2009) 742.

[14] P.Y. Chevalier, Thermochim. Acta 130 (1988) 33.

[15] G.M. Rao, D. Elwell, R.S. Feigelson, J. Electrochem. Soc. 122 (1981) 1708.

[16] U. Cohen, R.A. Huggins, J. Electrochem. Soc. 123 (1976) 381.

[17] L. Massot, P. Chamelot, F. Bouyer, P. Taxil, Electrochim. Acta 47 (2002) 1949.

[18] A.D. Graves, D. Inman, Nature 208 (1965) 481.

[19] P. Chamelot, P. Palau, L. Massot, A. Savall, P. Taxil, Electrochim. Acta 47 (2002) 3423.

[20] T. Berzins, P. Delahay, J. Am. Chem. Soc. 75 (1953) 555.

[21] P. Chamelot, P. Taxil, B. Lafage, Electrochim. Acta 39 (1994) 2571

[22] C. Hamel, P. Chamelot, P. Taxil, Electrochim. Acta 49 (2004) 4467.

[23] P. Chamelot, L. Massot, L. Cassayre, P. Taxil, Electrochim. Acta 55 (2010) 4758.

[24] P. Chamelot, B. Lafage, P. Taxil, Electrochim. Acta 43 (1997) 607.

[25] G. Hills, D.J. Schiffrin, J. Thompson, Electrochim. Acta 19 (1974) 657.

[26] C. Nourry, L. Massot, P. Chamelot, P. Taxil, Electrochim. Acta 53 (2008) 2650. 